\title{
A new fossil eomeropid (Insecta, Mecoptera) from the Jiulongshan Formation, Inner Mongolia, China
}

\author{
Junxia ZHANG \\ Chungkun SHIH \\ College of Life Sciences, Capital Normal University, \\ 105 Xisanhuanbeilu, Haidian District, Beijing, 100048 (P. R. China) \\ junxiazhang2008@foxmail.com \\ chungkun.shih@gmail.com \\ Julián Fernando PETRULEVIČIUS \\ Div. Paleozoología Invertebrados, Museo de La Plata-UNLP-CONICET, \\ Paseo del Bosque s/n, La Plata 1900 (Argentina) \\ levicius@fcnym.unlp.edu.ar \\ Dong REN \\ College of Life Sciences, Capital Normal University, \\ 105 Xisanhuanbeilu, Haidian District, Beijing, 100048 (P. R. China) \\ rendong@mail.cnu.edu.cn
}

Zhang J. X., Shih C., Petrulevičius J. F. \& Ren D. 2011. - A new fossil eomeropid (Insecta, Mecoptera) from the Jiulongshan Formation, Inner Mongolia, China. Zoosystema 33 (4): 443-450. DOI: 10.5252/z2011n4a2.

KEY WORDS

Insecta, Mecoptera, Eomeropidae, Middle Jurassic, China, new genus, new species.

\section{ABSTRACT}

A new genus and species of eomeropid, Jurathauma simplex n. gen., n. sp., is described from the Middle Jurassic of Inner Mongolia, China. It can be distinguished from all known eomeropid genera by a combination of these characters: two rows of cells formed by crossveins between costal margin and ScP; RP + MA with five branches; MP with five branches; and three anal veins. The presence of this new species and Tsuchingothauma shibi Ren \& Shih, 2005 of the same family in this locality suggests the early diversification of eomeropids with cockroach-like body during the Middle Jurassic. 


\author{
MOTS CLÉS \\ Insecta, \\ Mecoptera, \\ Eomeropidae, \\ Jurassique Moyen, \\ Chine, \\ genre nouveau, \\ espèce nouvelle.
}

\section{RÉSUMÉ}

Un nouveau Eomeropidae fossile (Insecta, Mecoptera) de la Formation Jiulongshan, Mongolie intérieure, Chine.

Un nouveau genre et une nouvelle espèce d'Eomeropidae, Jurathauma simplex n. gen., n. sp., est décrite du Jurassique Moyen de Mongolie intérieure, Chine. Il peut être différencié de tous les genres connus d'Eomeropidae par la combinaison des caractères suivants: deux rangées de cellules formées par des veines transversales entre la marge costale et le ScP; RP + MA avec cinq branches; un MP avec cinq branches; et trois veines anales. La présence de cette nouvelle espèce et de Tsuchingothauma shihi Ren \& Shih, 2005 de la même famille dans cette localité suggère une diversification précoce des Eomeropidae morphologiquement proches des blattes pendant le Jurassique Moyen.

\section{INTRODUCTION}

Mecoptera has a rather diverse fossil record. Up to now, 39 families, 207 genera with 703 species of fossil Mecoptera have been described, based on data from the EDNA site (http://edna.palass-hosting.org/ help.php). Eomeropidae Cockerell, 1909 (synonym Notiothaumatidae Esben-Petersen, 1921) is a small family of Mecoptera represented by only one extant species, Notiothauma reedi M'Lachlan, 1877. This living species, rare, primitive, and often regarded as a "living fossil", has been found only in the western slopes of the Andes of Southern Chile (Remington 1968; Peña 1968). This remarkable and unique insect has flat shaped body and incumbent wings. Notiothauma reedi is active during humid nights in Nothofagus forests and lays its eggs on ferns in captivity (Peña 1968).

Five fossil genera with eight species have been described hitherto, with ages ranging from the Middle Jurassic to the Late Eocene (Cockerell 1909; Ponomarenko \& Rasnitsyn 1974; Willmann 1978, 1987; Carpenter 1992; Novkshonov 1998; Ren \& Shih 2005; Archibald et al. 2005). Occurrences of these fossil eomeropids indicate that they were more diverse and widespread in the geological past than extant ones. The general external morphology of this family has not changed much from the Mesozoic.

Recently we collected two fossil eomeropids from the lacustrine sedimentary strata of the Jiulongshan Formation in Daohugou Village, Ningcheng County, Inner Mongolia, northeastern China. The age of the Jiulongshan Formation is considered as the Middle Jurassic (Ren et al. 1995, 2002, 2009; Tan \& Ren 2002; Chen et al. 2004; Gao \& Ren 2006; Tan et al. 2007).

Despite its Middle Jurassic age, the new Chinese eomeropids show extraordinary morphological similarity to their living relatives found in Chile (Crampton 1930; Mickoleit 1971). This similarity underscores the stasis of anatomical evolution. Indeed, extant eomeropids can be regarded as "living fossils" whose structures have remained little changed for over 165 million years. Furthermore, the new materials from China reveal that the early diversification of eomeropids with cockroach-like body or cockroach-type wings (Crampton 1931; Shields 1988; Whiting 2002) was well underway by the Middle Jurassic.

\section{MATERIAL AND METHODS}

This study is based on two specimens housed in the fossil insect collection of the Key Lab of Insect Evolution \& Environmental Changes, College of Life Sciences, Capital Normal University, Beijing, China (CNU, Dong Ren, Curator). The specimens were examined using a Leica MZ12.5 microscope, illustrated with the aid of a camera lucida. The body terminology used here is that of Mickoleit (1971, 1975 ) and the wing venation nomenclature of fossil and extant Mecoptera follows those of Kukalová-Peck (1991) and Kukalová-Peck \& Lawrence (2004). 

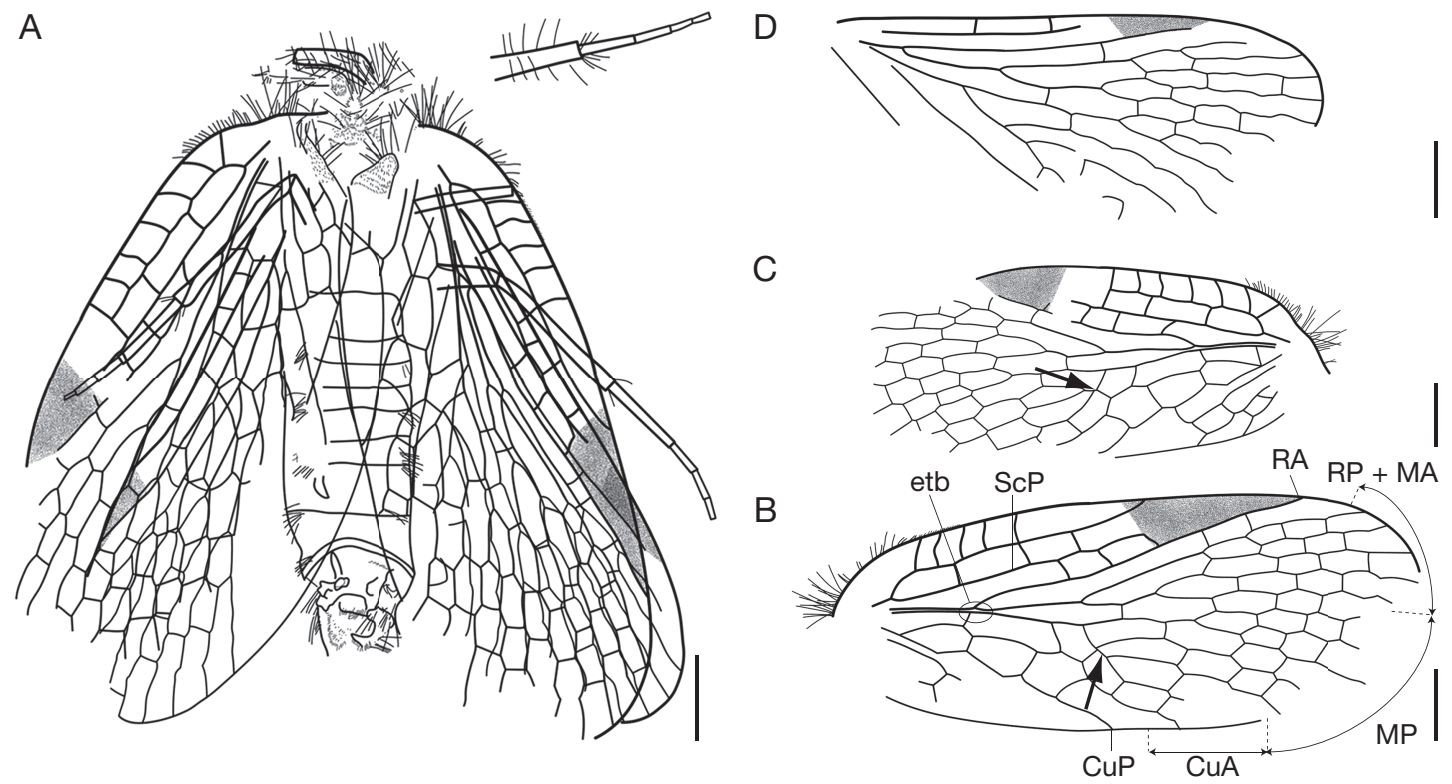

FIG. 1. - Jurathauma simplex n. gen., n. sp., holotype (CNU-MEC-NN2009001): A, body with wings; B, right forewing; C, left forewing; D, right hind wing. Arrows indicate venational variation. Abbreviations: see Material and methods. Scale bars: $2 \mathrm{~mm}$.

\section{ABBREVIATIONS}

etb Eomeropidae triadic branching;

$\mathrm{CuA}$ anterior cubitus;

$\mathrm{CuP}$ posterior cubitus;

MA anterior media;

MP posterior media;

RA anterior radius;

$\mathrm{RP} \quad$ posterior radius;

$\mathrm{ScP} \quad$ posterior subcosta.

\section{SYSTEMATICS}

Class INSECTA Linnaeus, 1758

Order MECOPTERA Packard, 1886

Family EOMEROPIDAE Cockerell, 1909

\section{Genus Jurathauma n. gen.}

Notiothauma - M'Lachlan 1877: 427-430 (part).

TYPE SPECIES. - Jurathauma simplex n. gen., n. sp.

ETYMOLOGY. - The generic name is a combination of the word Jurassic and thauma, a Greek word, meaning a wonderful thing or a marvel, from the recent genus of Eomeropidae Notiothauma M'Lachlan, 1877. Gender feminine.
DiAGNOSIS. - Simplified venation compared to other genera of the family: costal area traversed by one main veinlet and forming two rows of cells; RP + MA with five branches; MP with five branches; $\mathrm{CuA}$ double and $\mathrm{CuP}$ simple; three anal veins.

Jurathauma simplex n. gen., n. sp. (Figs $1 ; 2 \mathrm{~A}, \mathrm{~B}, \mathrm{D} ; 3$ )

TYPE MATERIAL. - Holotype (CNU-MEC-NN2009001) and paratype (CNU-MEC-NN2009002).

Type locality. - China. Daohugou Village, Shantou Township, Ningcheng County, Inner Mongolia; Jiulongshan Formation.

ETymology. - The specific name is derived from the Latin simplex (meaning "simple") referring to its simple venation.

MATERIAL EXAMINED FOR COMPARISON. - Two new specimens described herein: Tsuchingothauma shibi Ren \& Shih, 2005 (CNU-M-NN200401 and CNU-M-NN200402) from the Middle Jurassic of Jiulongshan Formation, Daohugou locality, and Typhothauma yixianensis Ren \& Shih, 2005 (CNU-M-LB200401) from the Late Jurassic to Early Cretaceous of Yixian Formation, Chaomidian locality. 

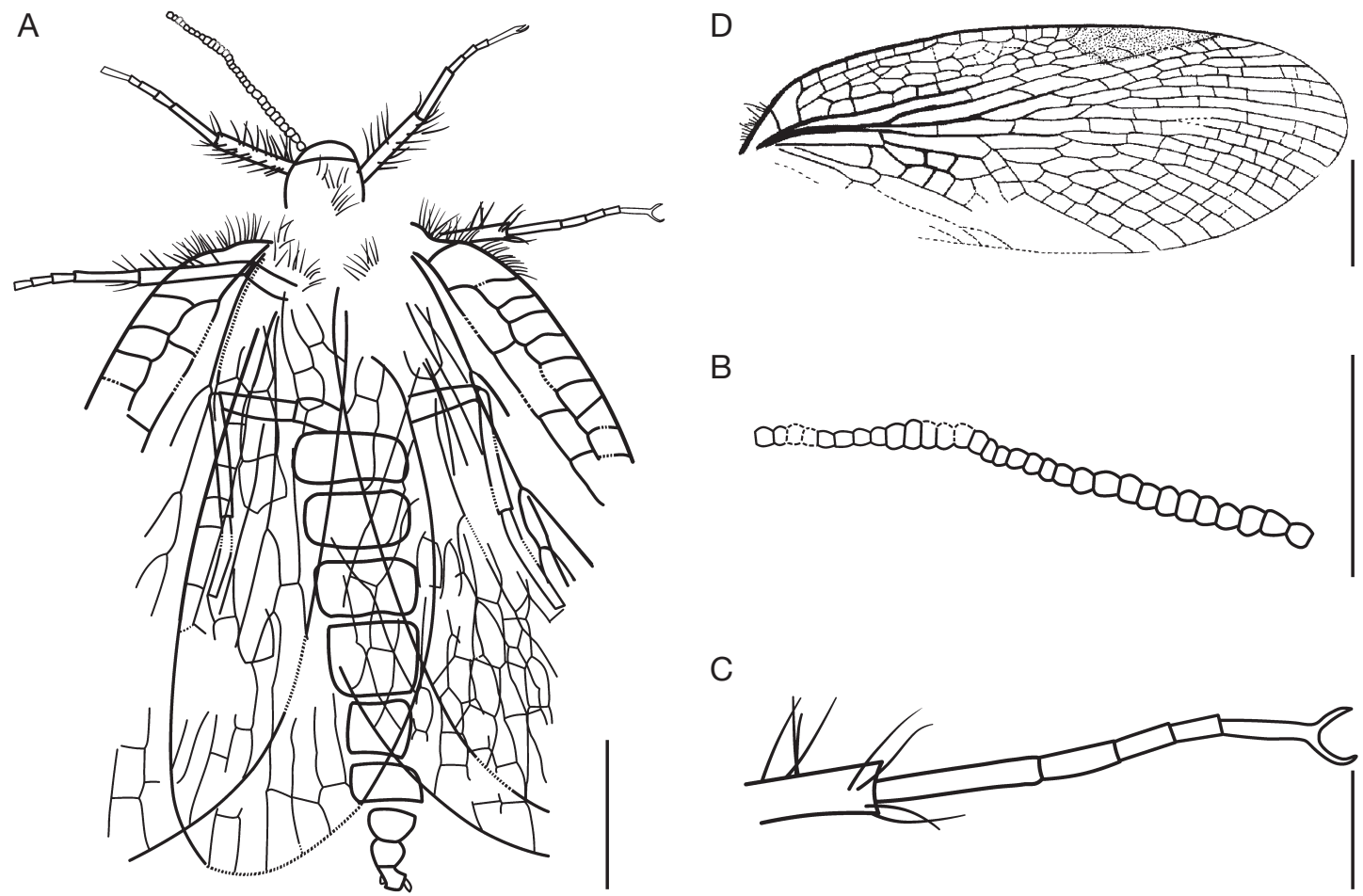

B

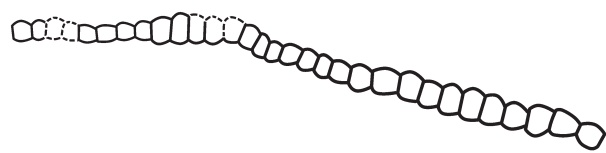

C

FIG. 2. - Jurathauma simplex n. gen., n. sp., ๆ paratype (CNU-MEC-NN2009002): A, body with wings; B, left antenna; C, right middle leg; D, Tsuchingothauma shihi Ren \& Shih, 2005 (CNU-M-NN200401), right forewing. Scale bars: A, 4 mm; B, 5 mm; C, 2 mm; D, 1 mm.

Distribution. - Daohugou Village, Shantou Township, Ningcheng County, Inner Mongolia, China; Jiulongshan Formation.

\section{DESCRIPTION}

Based mainly on the holotype, with supplemental information from the paratype.

\section{Holotype}

A complete male specimen preserved in dorsal view; wings almost symmetrically arranged, with a pair on each side slightly overlapped; body length (excluding antennae) $15 \mathrm{~mm}$; head and antennae not preserved (Figs 1A; 3A).

\section{Paratype}

A complete female specimen preserved in dorsal view; forewing and hind wing overlapped and partially preserved; body length (excluding antennae) $20 \mathrm{~mm}$; hypognathous head partially preserved; antennae incomplete with many antennomeres, filiform (Figs 2A, B; 3B, C).

Forewing length $16.1 \mathrm{~mm}$, width $6.2 \mathrm{~mm}$; apical margin of the forewing somewhat sharp-pointed (Fig. 1A-C). At very base of the costal margin, a cluster of less than 20 heavy setae (up to $1.35 \mathrm{~mm}$ long) for an area of about $1.4 \mathrm{~mm}$ wide; distally, an area about $2 \mathrm{~mm}$ wide with shorter (up to $0.3 \mathrm{~mm}$ long) setae (measurements based on left forewing); costal margin continuing pubescent; costal area narrow basally to humeral vein, distally broadened, traversed by two rows of cells and a strong and longitudinal secondary vein parallel to the costal margin with four (in right wing) and seven (in left wing) crossveins; three crossveins from $\mathrm{ScP}$ to the secondary longitudinal vein; $\mathrm{ScP}$ distally vanishing and not reaching anterior wing margin; pterostigma present, apical part of RA vanishing or obscure in this area; $\mathrm{RA}, \mathrm{RP}+\mathrm{MA}$ and 

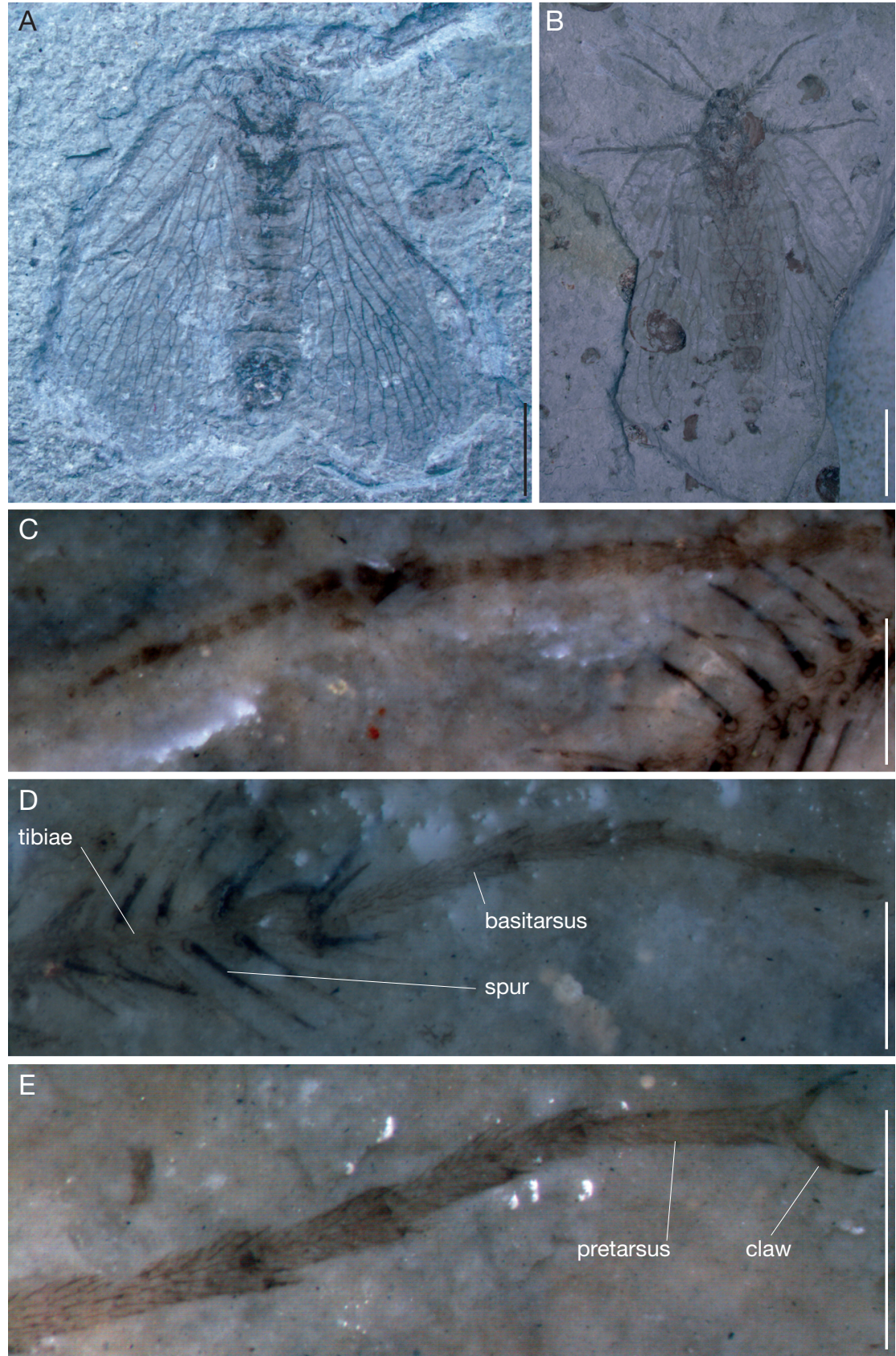

FIG. 3. - Jurathauma simplex n. gen., n. sp.: A, holotype (CNU-MEC-NN2009001); B, paratype (CNU-MEC-NN2009002); C, left antenna of paratype; $\mathbf{D}$, right fore leg of paratype; $\mathbf{E}$, right middle leg of paratype. Scale bars: $A, 4 \mathrm{~mm} ; \mathrm{B}, 5 \mathrm{~mm} ; \mathrm{C}, \mathrm{D}, \mathrm{E}, 1 \mathrm{~mm}$. 
MP forming the "Eomeropidae triadic branching" (Fig. 1B); RA diverging anteriorly from RP + MA, as in Tsuchingothauma shibi Ren \& Shih, 2005 (Fig. 2D); RP + MA continuing straight with R; RA simple, weakly zigzagged; RP + MA with two main branches, anterior one with three terminal branches, posterior one with two terminal branches; three setae on $\mathrm{Cu}$ just before its bifurcation, a longer seta in the beginning of $\mathrm{CuA}$; MP bifurcated into two main branches, MP1 +2 continuing the same direction, MP3 +4 diverging posteriorly at a nearly straight angle; MP1 single, MP2 double, $\mathrm{MP} 3$ single, $\mathrm{MP} 3+4$ joined with $\mathrm{CuA} 1+2$ by a short distance in left wing, MP3 +4 only touching $\mathrm{CuA} 1+2$ in right wing (see arrows in Figure 1B, C); $\mathrm{CuA} 1+2$ free (?); $\mathrm{CuA} 3+4$ strongly and curvy zigzagged by crossveins, bent sharply posteriad approximately at branching of $\mathrm{MP}$, only with one terminal branch; CuP single, zigzagged by crossveins; three simple anal veins. All veins thickened in basal parts, then narrower; no coloration detected. Entire forewing with many crossveins and long hexagonal cells.

Hind wing length $12.5 \mathrm{~mm}$, width $5.0 \mathrm{~mm}$; veins partly preserved (Fig. 1A, D). Costal area with few (at least three) crossveins; pterostigma present; apical part of RA vanished or obscure in this area; RP + MA arising from RA at acute angle; RA continuing stem of R; RA simple, posteriorly limiting pterostigma; RP + MA divided in two main branches, anterior one with three terminal branches, posterior one with two terminal branches; MP1 single, MP2 double, MP3 single, $\mathrm{MP} 3+4$ only touching $\mathrm{CuA} 1+2$ in right wing (as in recent Notiothauma); CuA incompletely preserved. All veins thickened in basal parts, then narrower; no trace of coloration. Compared to the forewing, the hind wing smaller in size and with fewer crossveins and long hexagonal cells.

Prothorax poorly preserved. Meso- and metanotum distinctly larger than pronotum. There is a certain amount of crinite on the thorax (Figs 1A; 3A, B).

Legs densely clothed with transverse rows of short setae. Femora stout. Tibiae somewhat longer and slender, with many conspicuous spines and 2 terminal spurs. Tarsi 5-segmented, basitarsus longest. Pretarsus with 2 lateral claws (Figs 2C; 3D, E).

Abdomen elongate, tapering apically, with 9 visible segments. Segments 8 and 9 abruptly more slender than 1-6. Lateral tergal horns in segment 7. Gonostylus partially preserved (Fig 1A).

\section{DISCUSSION}

The new genus and species is attributed to the Eomeropidae because of several characters and features: the presence of parallel and secondary veins in costal area, "Eomeropidae triadic branching", presence and distribution of long setae on wings, and the general flat aspect of the insect body with strong and particularly disposed spines and hypognathous head.

The new genus differs from all other genera of the family in its simpler venation, with fewer longitudinal veins and crossveins, resulting in fewer cells. Jurathauma n. gen. (Fig. 1B) differs from Tsuchingothauma Ren \& Shih, 2005 (Fig. 2D) by the presence of two rows of cells in the costal area of forewing vs. five rows in Tsuchingothauma; Sc simple; both RP + MA and MP with fewer branches (both RP + MA and MP with five vs. both RP + MA and MP with nine in Tsuchingothauma); CuA double, only with one terminal branch, whereas in Tsuchingothauma, there are at least 2 or 3 terminal branches; wings with fewer crossveins and cells. The new genus can also be distinguished from Typhothauma Ren \& Shih, 2005 by the following characteristics: 1) costal area traversed by one main veinlet and forming two rows of cells; 2) CuA double, whereas in Typhothauma there are three terminal branches; 3) anal area with only three veins.

There is a difference between the right and left forewings of the holotype in the medial and cubital veins: $\mathrm{MP} 3+4$ joined with $\mathrm{CuA} 1+2$ by a short distance in left wing, MP3 + 4 only touching $\mathrm{CuA} 1+2$ in right wing (see arrows in Fig. 1B, C). Carpenter (1992) also reported differences present in eomeropids. These differences imply possible variations in the venation at individual or species level in Eomeropidae. Such an important variability 
could induce to wrong interpretations in taxonomy studies of isolated wings.

The holotype is the first recognized male in the fossil record of Eomeropidae so far. The holotype has a body length of $15 \mathrm{~mm}$, the paratype, a female, a body length of $20 \mathrm{~mm}$, and a female of T. shibi has a body length of $22 \mathrm{~mm}$ (body length is measured excluding antennae). Based on this limited number of fossil specimens, it seems that the female eomeropids are larger than the males during the Middle Jurassic. Besides potential size difference between females and males, there are many other factors impacting body size, for example, individual diet, nutrition, metabolism, growth, mutations, etc.

The setae and spines of the new species, such as those occurring at the base of the wing, legs, thorax and abdomen, have similar distribution as those of $N$. reedi (Crampton 1930). The preserved fossil specimens of the new species and Tsuchingothauma shibi suggest that they held wings in roof-like position when in repose, which is consistent with $N$. reedi holding its wings in the incumbent position in repose (Crampton 1930). Notiothauma reedi was reported to have an extremely depressed and flattened form when in a state of repose, indicating that it may hide under loose bark of trees or stones (M'Lachlan 1877). It is likely, by inference, that the fossil eomeropids might have had the same behavior.

\section{Acknowledgements}

We thank Bruce Archibald, André Nel and Annemarie Ohler for their review and their valuable and helpful comments. The research was supported by the National Natural Science Foundation of China (no. 40872022, 31071964), the Beijing Natural Science Foundation (No.5082002) and the Scientific Research Key Program and PHR Project of Beijing Municipal Commission of Education. JFP thanks the National Research Council of Argentina (CONICET) for funds: PIP 6393, PIP 0377 and BEJI. We also thank the USA National Science Foundation (NSF) grants DEB-0345750 and DEB-0919071 for technical support.

\section{REFERENCES}

ARChibald S. B., Rasnitsyn A. P. \& AKhMetiev M. A. 2005. - The ecology and distribution of Cenozoic Eomeropidae (Mecoptera), and a new species of Eomerope Cockerell from the Early Eocene McAbee locality, British Columbia, Canada. Annals of the Entomological Society of America 98: 503-514.

CARPENTER F. M. 1992. - Treatise on Invertebrate Palaeontology, Part R, Arthropoda 4 (3). Geological Society of America and University of Kansas Press, Lawrence: 380-395.

Chen W., Ji Q., Liu D. Y., Zhang Y., Song B. \& LIU X. Y. 2004. - Isotope geochronology of the fossil-bearing beds in the Daohugou Area, Ningcheng, Inner Mongolia. Geological Bulletin of China 23: 1165-1169.

Cockerell T. D. A. 1909. - Description of Tertiary insects, VI. American Journal of Science 27: 381387.

CRAmpton G. C. 1930. - The wings of the remarkable archaic mecopteran Notiothauma reedi M'Lachlan with remarks on their protoblattoid affinities. Psyche 37 (1): 83-103.

Crampton G. C. 1931. - The genitalia and terminal structures of the male of the archaic Mecopteran, Notiothauma reedi, compared with related holometabola from the standpoint of phylogeny. Psyche 38 (1): $1-21$

GAO K. Q. \& REN D. 2006. — Radiometric dating of ignimbrite from Inner Mongolia provides no indication of a Post-Middle Jurassic Age for the Daohugou Beds. Acta Geologica Sinica 80: 42-45.

KuKALOVÁ-PECK J. 1991. - The Insects of Australia. $2^{\text {nd }}$ Edition. Melbourne University Press, Carlton, 141-179.

Kukalová-Peck J. \& Lawrence J. F. 2004. - Relationships among coleopteran suborders and major endoneopteran lineages: evidence from hind wing characters. European Journal of Entomology 101: 95-144.

MicKOLEIT G. 1971. — Das Exoskelet von Notiothauma reedi M'Lachlan, ein Beitrag zur Morphologie und Phylogenie der Mecoptera (Insecta). Zeitschrift für Morphologie der Tiere 69: 318-362.

MicKoleIT G. 1975. — Die Genital und Postgenitalsegmente der Mecoptera-Weibchen (Insecta, Holometabola). I. Das Exoskelet. Zeitschrift für Morphologie der Tiere 80: 97-135.

M'LaCHLAN R. 1877. - On Notiothauma reedi, a remarkable new genus and species of Neuroptera from Chile, pertaining to the family Panorpidae. Transactions of the Entomological Society of London, Part IV: 427-430.

Novokshonov V. G. 1998. - Some problems of scorpionfly (Mecoptera) evolution. Entomological 
Review 78 (3): 378-390.

PeÑA G. L. E. 1968. — Natural history notes on Notiothauma. Discovery 4 (1): 42-44.

Ponomarenko A. G. \& Rasnitsyn A. P. 1974. - New Mesozoic and Cenozoic Protomecoptera. Paleontological Journal 8: 493-507.

REMINGTON C. L. 1968. — A rare and primitive winged Insect from Chile. Discovery 4 (1): 37-41.

Ren D., Lu L. W., Guo Z. G. \& JI S. A. 1995. — Faunae and Stratigraphy of Jurassic-Cretaceous in Beijing and the Adjacent Areas. Seismic Publishing House, Beijing. 222 p. (in Chinese, English abstract).

Ren D., GaO K. Q., Guo Y. G., Ji S. A., Tan J. J. \& SonG Z. 2002. - Stratigraphic division of the Jurassic in the Daohugou Area, Ningcheng, Inner Mongolia. Geological Bulletin of China 21: 584-591.

REN D. \& SHIH C. K. 2005. - The first discovery of fossil Eomeropids from China (Insecta, Mecoptera). Acta Zootaxonomica Sinica 30 (2): 275-280.

Ren D., Labandeira C. C., Santiago-Blay J. A., Rasnitsyn A., Shih C. K., BashKuev A., LOgan M. A. V., Hotton C. L. \& Dilcher. D. 2009. -
A probable pollination mode before angiosperms: Eurasian, long-proboscid scorpionflies. Science 326: 840-847.

SHIELDS O. 1988. - Mesozoic history and neontology of Lepidoptera in relation to Tricoptera, Mecoptera, and angiosperms. Paleontological Journal 62 (2): 251-258.

Tan J., Huang D. Y. \& Ren D. 2007. — First record of fossil Mesocupes from the Middle Jurassic of Inner Mongolia, China (Coleoptera: Archostemata). Acta Geologica Sinica 81 (5): 688-696.

TAN J. \& REN D. 2002. — Palaeoecology of insect community from Middle Jurassic Jiulongshan Formation in Ningcheng County, Inner Mongolia, China. Acta Zootaxonomica Sinica 27: 428-434.

Whiting M. F. 2002. - Mecoptera is paraphyletic: multiple genes and phylogeny of Mecoptera and Siphonaptera. Zoologica Scripta 31 (1): 93-104.

Willmann R. 1978. - Mecoptera (Insecta, Holometabola). Fossilium Catalogus (Animalia) 124: 1-139.

WiLLMANN R. 1987. - The phylogenetic system of the Mecoptera. Systematic Entomology 12: 519-524.

Submitted on 27 November 2010; accepted on 4 April 2011. 